ZOOLOGIA 27 (2): 258-262, April, 2010

doi: $10.1590 /$ S1984-46702010000200013

\title{
Taxonomic revisionary notes on some Neotropical Coenosiini (Diptera: Muscidae)
}

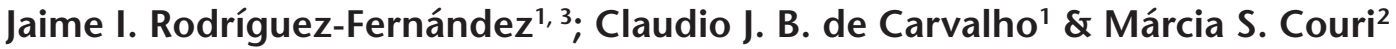

\author{
${ }^{1}$ Departamento de Zoologia, Universidade Federal do Paraná. Caixa Postal 19020, 81531-980 Curitiba, Paraná, Brasil. \\ 2 Departamento de Entomologia, Museu Nacional, Universidade Federal do Rio de Janeiro. Quinta da Boa Vista, $20940-040$ \\ Rio de Janeiro, Rio de Janeiro, Brazil. \\ ${ }^{3}$ Corresponding author. E-mail: formycusub@yahoo.com.br
}

\begin{abstract}
Coenosiinae is an important component of the Neotropical Muscidae diversity due to the high diversity of species and high population numbers. Based on the examination of type-specimens of some species of Coenosiini, the following taxonomic changes are proposed: Neodexiopsis medinai Snyder, 1957 stat. rev., Pilispina xanthogaster (Albuquerque, 1958) comb. nov., Pilispina differa Couri \& Carvalho, 1999 is a junior synonym of Pilispina pilitibia Albuquerque, 1954, Neodexiopsis barbiventris Couri \& Albuquerque, 1979 is a junior synonym of Neodexiopsis flavipalpis Albuquerque, 1956 and a neotype is proposed for Coenosia latitibia Albuquerque 1957. In all cases, remarks include reevaluation of relevant characters.
\end{abstract}

KEY WORDS. Coenosiinae; new combination; revalidation; synonymy; taxonomy.

Coenosiinae is the most diverse subfamily of Neotropical Muscidae and is considered to be one of the apical groups within the family (CarvalHo 1989b). Two tribes are currently recognized, Limnophorini and Coenosiini (CARvalHo et al. 2005), but only the monophyly of the latter is strongly supported (CourI \& PONT 2000). The Coenosiini are very abundant in well-preserved forests (COSTACURTA et al. 2003a, b) and are usually collected by sweeping over grass or other short vegetation (SNYDER 1958). The Coenosiini are an important component of the Neotropical Muscidae diversity due to the high diversity of species and high population numbers (RodrígUEZ-FerNández et al. 2006).

Following a revision of the type material deposited in the collection of the Museu Nacional (Rio de Janeiro), this contribution proposes several taxonomic changes for species included in the Coenosiini.

\section{MATERIAL AND METHODS}

The material studied is deposited in the following institutions: Coleção de Entomologia Pe. J.S. Moure, Departamento de Zoologia, Universidade Federal do Paraná, Curitiba (DZUP); Museu Nacional, Universidade Federal do Rio de Janeiro, Rio de Janeiro (MNRJ), and United States National Museum, Washington, D.C. (USNM).

The morphological terminology follows McAlpine (1981) and Hucketт \& Vockeroth (1987), with a few exceptions indicated by CarvalHo (1989a). The following abbreviations were used: (DC) dorsocentral setae, (PD) posterodorsal setae, and (AV) anteroventral setae.In this paper, only a reference to the original description of a species is given. A complete list of references for each species can be found in CARVALHO et al. (2005).

\section{TAXONOMY}

\section{Pilispina pilitibia Albuquerque, 1954}

Figs 1-3

Pilispina pilitibia Albuquerque, 1954: 180.

Parvomusca differa Couri \& Carvalho, 1993: 732. Syn. nov.

Pilispina differa; Couri \& Pont 1999: 99 (key, synonym of Pilispina).

Type material examined. Pilispina pilitibia: holotype male (MNRJ) labeled: "Itatiaia, 2000m P.Wichart, II/[19]41"; "HOLÓTIPO [red label], nº4974" [Albuquerque handwriting]; "Pilispina pilitibia" [Albuquerque handwriting]. Parvomusca differa: paratype male (DZUP) labeled: "CURITIBA-PR [Paraná]/ 03.XI.1989./Maia, J.C.S. LEG.”; “CAPÃO DA IMBUIA/MALAISE TRAP"; "PARATYPO" [Green label]; "Parvomusca differa/Couri \& Carvalho, sp. nov./M. S. Couri det. 92" [handwriting]; "1 ơ...DZUP"; "Pilispina pilitibia/Albuquerque, 1954/J.I.R. Fernández det. 2008".

Distribution. Brazil: Rio de Janeiro, Paraná.

Remarks. Albuquerque (1954) erected the genus Pilispina based on a single asymmetrical specimen of the type-species, P. pilitibia (Figs 1-3). The specimen has one presutural DC seta on the left side, two on the right side, and three postsutural setae on either side. Mistakenly, the author described the DC setae pattern as $2+2$. Latter, CourI (2000) noted the error in the interpretation of the number of postsutural setae and corrected 
the DC pattern to $2+3$. However, examination of additional specimens from the type-locality indicates that the DC pattern for this species is actually 1+3 (Fig. 2). Parvomusca differa was tentatively described in Parvomusca Medeiros, 1980, a monobasic genus, mainly based on similarities shared with the typespecies, P. paula Medeiros, in the chaetotaxy of the hind leg. Latter, Couri \& Carvalho (1993) questioned the inclusion of $P$. differa in Parvomusca, noting the following: "but the general aspect is not the same, $P$. differa was included in this genus tentatively, until other studies clarify the position of the Neotropical Coenosiinae genera." After the correct interpretation of the DC setae of $P$. pilitibia and comparison of the holotype of this species with that of $P$. differa, we herein propose the synonym of these two species. Additionally, we have observed that the posterior femur of $P$. pilitibia has three preapical setae and not two, as described in the literature.

\section{Pilispina xanthogaster (Albuquerque, 1958) comb. nov.} Figs 4-6

Levallonia xanthogaster Albuquerque, 1958: 101.

Levallonia medinai; Couri \& Albuquerque 1979: 516. Pilispina medinai; Couri \& Pont 1999: 99 (key).

Type material examined. Levallonia xanthogaster male (MNRJ) labeled: "Petrópolis; Estado do Rio, Le Vallon, Alt. Mosella, Albuquerque, 1/II-8/III/[19]57"; "HOLOTIPO [red label], $\mathrm{n}^{\circ}$ 5360" [Albuquerque handwriting]; "Levallonia xanthogaster" [Albuquerque handwriting].

Distribution. Brazil: Rio de Janeiro.

Remarks. The examination of the type material of $P$. xanthogaster enabled the reevaluation of the following characters mentioned in the original description: pollinosity on head and mesonotum, observed under white light, grey (and not golden); apex of flagellum rounded (and not pointed); and vitta on mesonotum absent (and not three faint ones) (Fig. 4). Other morphological differences between $P$. xanthogaster and other related species are in the table I. Originally ALBUQUERQUe (1958) described the second and the third (posterior) frontal setae of the head as reclinate. This led to some discussions by subsequent authors (Hennig 1965, Couri \& Pont 2000) because in all other genera of Neotropical Coenosiini only the last pair (the third one) is reclinate and only non-Neotropical genera species of Coenosiini have the second and the third (posterior) frontal setae reclinated. After examining the holotype of $P$. xanthogaster we have concluded that the interpretation of ALBUQUERQUE (1958) was wrong and that only the last pair of frontal setae is reclinate as in all other genera of Neotropical Coenosiini and,contrasting with the state found in other, nonNeotropical Coenosiini genera, in which the second and third frontal setae are clearly reclinate, and the curvature of the second seta follows the curvature of the third (Fig. 4). Historical differences in taxonomic concepts associated with $P$. xanthogaster are in the table II.

\section{Neodexiopsis flavipalpis Albuquerque, 1956 Figs 7-8}

Neodexiopsis flavipalpis Albuquerque, 1956: 198. Neodexiopsis barbiventris Couri \& Albuquerque, 1979: 502. Syn. nov.

Type material examined. Neodexiopsis flavipalpis: holotype: male (MNRJ) labeled: "Itatiaia, L. [lake] Azul, E. do Rio [Rio de Janeiro State], Trav. [L. Travassos], [R.] Barth, [D.] Albuquerque, [A.R.R.] Barros col., 26/IX/[1]954; $n^{\circ} 4755$ [Albuquerque handwriting]"; "HOLÓTIPO" [red label]; "Neodexiopsis flavipalpis"

Table I. Morphological differences between N. medinai and P. xanthogaster based on the examination of type material.

\begin{tabular}{lcc}
\hline \multicolumn{1}{c}{ Character } & N. medinai & P. xanthogaster \\
\hline Apical scutellar setae related to the sub-basal ones & a little shorter & much shorter \\
Length of the gena related to the flagellum & 0.5 times & 0.75 times \\
Number of preapical setae on posterior femur & 3 & 2 \\
Stripes on mesonotum & present & Absent \\
Color of legs & yellow & Brown \\
Number of AD setae on middle third of posterior tibia & 1 & 2 \\
Number of PD setae on middle third of posterior tibia & present & 2 \\
Median seta on posterior tibia & Absent \\
\hline
\end{tabular}

Table II. Historical synopsis of the different taxonomic concepts of N. medinai, N. cavalata and P. xanthogaster.

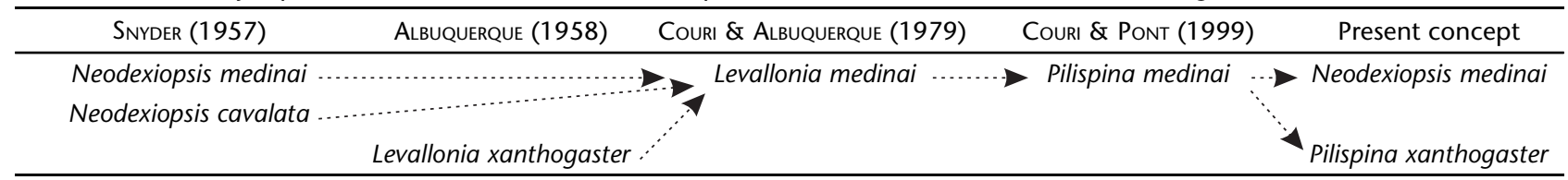



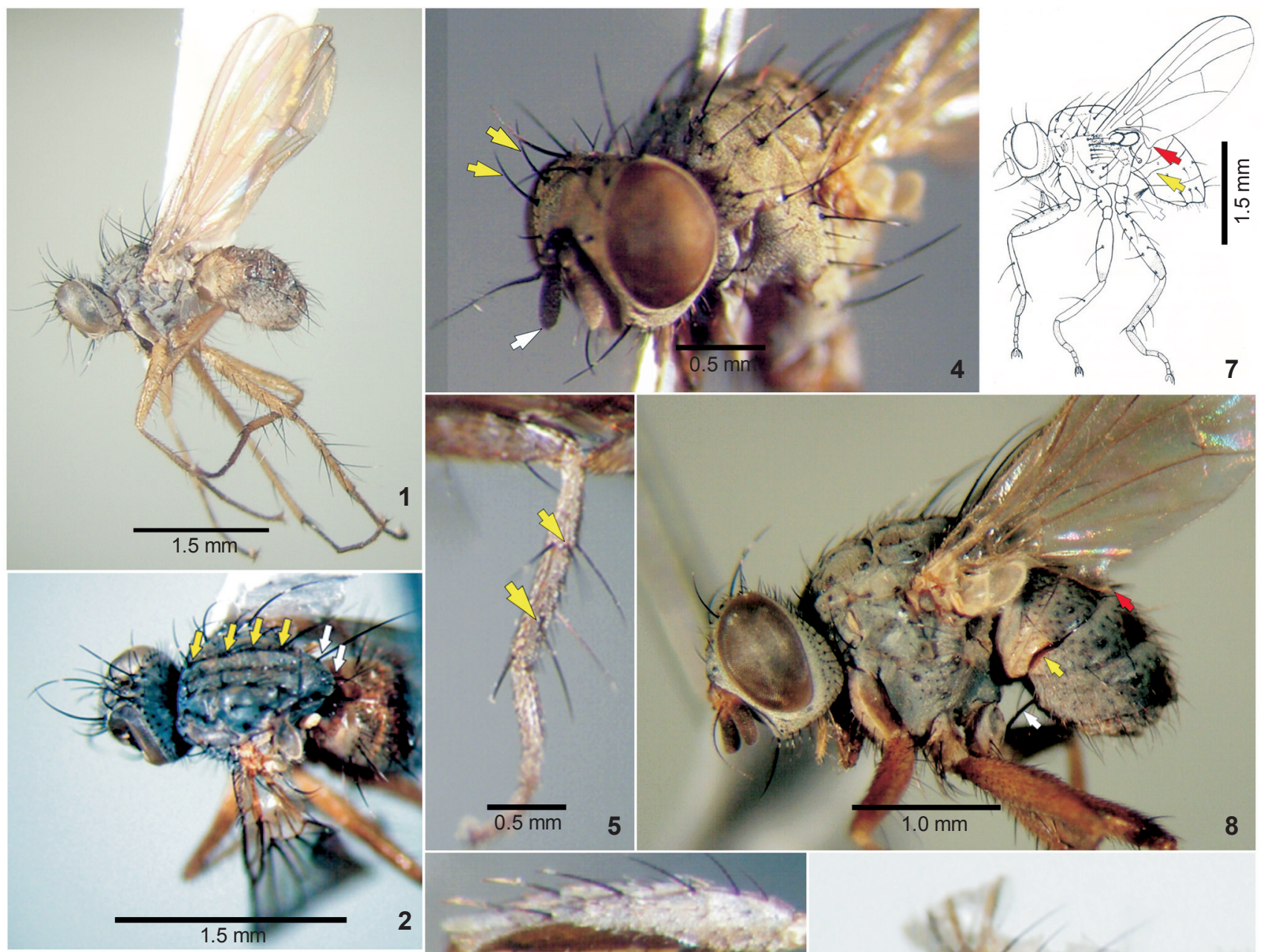

1

(1)

(1)

7
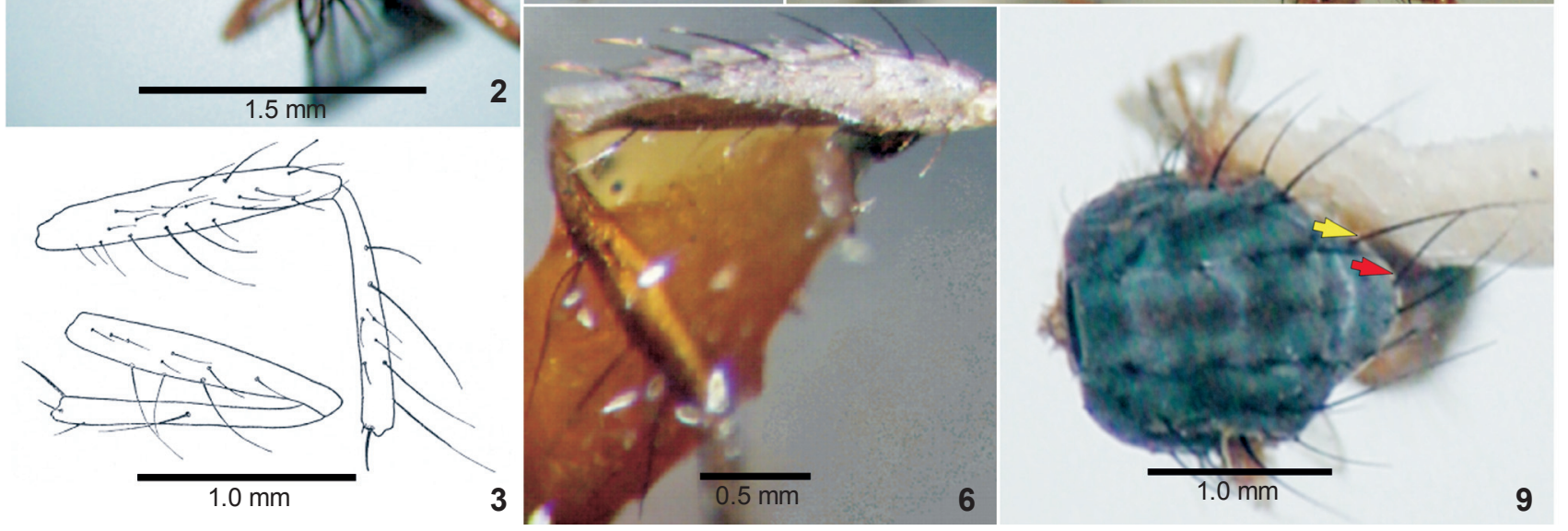

Figures 1-9. (1-3) Pilispina pilitibia: (1) habitus; (2) DC setae (yellow arrows) and scutellar setae (white arrows); (3) mid (lower) and hind (upper) legs in anterior view redrawed from AlBUQUeRQue (1954). (4-6) Pilispina xanthogaster: (4) habitus, second and the third frontal pairs of setae (yellow arrows), pollinosity on head and mesonotum and apex of flagellum rounded (white arrows); (5) hind tibia in anterior view and AD setae on middle third of posterior tibia (yellow arrows), (see Tab. I); (6) colour of the hind femur in anterior view. (7-8) Neodexiopsis flavipalpis: (7) modification with a lobe of the male wing (red arrow), third and fourth tergites modified (yellow arrow) and presence of a group of strong, comb-like setae on sternite 4 (white arrow), redrawed from Courl \& Albuquerque (1979); (8) same as figure 7. (9) Neodexiopsis medinai: apical scutelar setae (red arrow) a little shorter related to the subbasal ones (yellow arrow). 
[Albuquerque handwriting]. Neodexiopsis barbiventris: holotype: male (MNRJ) labeled: "Itatiaia, L. [lake] Azul, 19-21/VI/[19]55, [D.] Albuquerque, [A.R.R.] Barros, Pearson [Albuquerque handwriting]"; "HOLÓTIPO" [red label]; "Neodexiopsis barbiventris Couri \& Albuquerque, 1979" [Couri handwriting].

Distribution. Brazil: Rio de Janeiro, Paraná.

Remarks. This is a typical species of the ovata- group of Neodexiopsis Malloch, 1920, proposed by SNYDER (1958). Males and females of this group are easily differentiated from congeners by modifications in the anal area of the wing. In males, this area is shaped like a lobe (Figs 7 and 8). In females, it is more angular than in other species of Neodexiopsis (SNYDER 1958: figs 1-13 and 16). Additionally, the following modifications in the male abdomen are unique for this group of species: the abdomen, in lateral view, is short and distinctly oval; tergites 3-5 are conspicuously narrow ventrally, but the fifth sternite is more elongated dorsally and a small lateral posterior portion of the third abdominal tergite, and the anterior portion of the forth abdominal tergite are shiny and without pollinosity (Fig. 8) (SNYDER 1958). In his original description of N. flavipalpis, Albuquerque (1956) did not mention the modification in the anal area of the male wing. Subsequently, Couri \& Albuquerque (1979) represented the modification of the male wing in a figure in their description of N. barviventris (Fig. 7). ALBUQUERQUE (1956) also failed to note the presence of a group of strong, comb-like setae on the abdominal sternite 4 of $N$. flavipalpis. This autoapomorphic character was subsequently described for N. barbiventris by Couri \& Albuquerque (1979), and the specific epithet, barbiventris, refers to the condition (Figs 7 and 8). After detecting the afore mentioned problems in the original description of $N$. flavipalpis, and based on the examination of the holotypes of $N$. flavipalpis and N. barbiventris, we herein propose the synonym of these two species.

\section{Neodexiopsis medinai Snyder, 1957 stat. rev. Fig. 9}

Neodexiopsis medinai Snyder, 1957: 223.

Levallonia medinai; Couri \& Albuquerque 1979: 516.

Pilispina medinai; Couri \& Pont 1999: 99 (key).

Neodexiopsis cavalata Snyder, 1957: 224.

Type material examined. Neodexiopsis medinai male (USNM) labeled: "El Yunque, P.R., March 20-22, 1954 (J. Maldonado \& S. Medina)". "Holotype o'\&/Neodexiopsis medinai/ Snyder" (handwritting red label). Neodexiopsis cavalata male (USNM) labeled: "El Yunque, P.R., March 20-22, 1954 (J. Maldonado \& S. Medina)". "Holotype $\sigma^{\top} /$ Neodexiopsis cavalata/ Snyder" (handwriting red label).

Distribution: Puerto Rico.

Remarks. Couri \& Albuquerque (1979) proposed the synonymy of Levallonia xanthogaster Albuquerque, 1958, Neodexiopsis medinai Snyder, 1957 and Neodexiopsis cavalata Snyder, 1957. Based on one synapomorphy, a reduction in the length of the apical scutellar setae, Couri \& PONT $(1999,2000)$ synonimyzed some phylogenetically related Coenosiini genera under Pilispina (Levallonia Albuquerque, 1958, Noelia Albuquerque, 1957, Parvomusca, and Cholomyioides Albuquerque, 1954). The examination of the type material of L. xanthogaster and $N$. medinai revealed that they are different species (Figs 46 and 9), as shown in table I. Consequently, the specific status of $N$. medinai Snyder is herein revalidated (different taxonomic positions shown in table II). Neodexiopsis cavalata is maintained as a synonym of $N$. medinai, and L. xanthogaster received a new combination as indicated above.

\section{Coenosia latitibia Albuquerque, 1957}

Coenosia latitibia Albuquerque, 1957: 362.

Type material examined. Neotype: male (DZUP) labeled: "BRASIL PR [Paraná] Antonina/Reserva Biol. Sapitundava/ 21.XII.1987/Lev Ent. PROFAUPAR"; "Plumispina sp. nov. 2/ J.I.Rodríguez-Fernández/det. 2003"; "NEÓTIPO" [red label]. Additional material examined. "BRASIL PR Antonina/Reserva Biol. Sapitundava/21. IX.1987 (1 male, DZUP), 23.XI.1987 (1 male, DZUP), 07.XII.1987 (1 male, DZUP), 26.X.1987 (1 male, DZUP), 02.XI.1987 (2 males, DZUP), 12.X.1987 (1 male, DZUP), 14.XII.1987 (1 male, DZUP), 28.XII.1987 (1 male, DZUP), 07.IX. 1987 (1 male, DZUP), 16.XI.1987 (1 male, MNRJ)/Lev Ent. PROFAUPAR"; "Plumispina sp. nov. 2/J.I.Rodríguez-Fernández/ det. 2003".

Distribution. Brazil: Rio de Janeiro, Paraná.

Remarks. In the description of C. latitibia, ALBUQUERQUE (1957) wrote the possibility that this species belong to another genus. Years later, CourI \& CARvalHo (2002) placed C. latitibia on a list of species that are not included in any key to the identification of species of Coenosia and noted that the Neotropical Coenosia needs to be revised. When the identification is based in the last key to the Neotropical genera of Muscidae (CARvalHo 2002), C. latitibia may be erroneusly assigned as a species of Neodexiopsis, Plumispina, Pilispina (see above) or Cordiluroides By the combination of autapomorphic characters. The International Code of Zoological Nomenclature (ICZN 1999: articles 75.3.1 and 75.3.4) states that a neotype may be designed if the author includes (1) "a statement that it is designated with the express purpose of clarifying the taxonomic status or the type locality of a nominal taxon" and (2) the "reasons for believing the namebearing type specimen(s) (i.e. holotype, or lectotype, or all syntypes, or prior neotype) to be lost or destroyed, and the steps that had been taken to trace it or them". After examining all type material of the Coenosiini described by Dalcy de Oliveira Albuquerque, deposited at MNRJ, we have concluded that the type-material of C. latitibia is lost, as indicated by Lopes et al. (1997). Thus, a neotype is herein designated.

\section{ACKNOWLEDGEMENTS}

JIRF thanks Valéria C. Maia (Museu Nacional, Rio de Janeiro) and Nancy Orellana (Instituto Oswaldo Cruz, Rio de Janeiro) for all support during the scientific visits to their insti- 
tutions. JIRF also thanks Ana Paula Marques-Costa (Universidade Federal do Paraná - UFPR) for taking photographs of the type material deposited at USNM; to the people of the Laboratorio de Sistemática e Ecologia de Coleoptera (UFPR) for their assistance in taking photographs; to Marcio Pie (UFPR) for the English revision; to Kirstern L.F. Haseyama (UFPR), James O'Hara (Agriculture and Agri-Food Canada), Gabriel Mejdalani (Museu Nacional, Rio de Janeiro), Ana DalMolin (Texas A\&M University), and two anonymous referees for reviewing the manuscript. CJBC and MSC are fellows of CNPq (processes 302454/2005-5 and 301301/20077, respectively). JIRF thanks the Program of Qualification in Taxonomy (PROTAX-CNPq) for providing a Post-doctoral fellowship.

\section{LITERATURE CITED}

Albuquerque, D. DE O. 1954. Fauna do Distrito Federal. XV: Descrição de dois gêneros e quatro espécies novas de Coenosiinae (Diptera, Muscidae). Revista Brasileira de Biologia 14: 177-186.

Albuquerque, D. De O. 1956. Duas espécies novas de "Neodexiopsis" Mall., 1920 (Diptera, Muscidae). Revista Brasileira de Biologia 16: 195-200.

Albuquerque, D. De O. 1957. Um gênero e duas novas espécies de "Coenosiinae" do Brasil (Diptera, Muscidae). Revista Brasileira de Biologia 17: 359-365.

Albuquerque, D. De O. 1958. Descrição de um gênero e uma espécie nova de "Coenosiinae" (Diptera, Muscidae). Revista Brasileira de Biologia 18: 101-104.

Carvalho, C.J.B. De. 1989a. Revisão das espécies e posição sistemática de Palpibracus Rondani (Diptera, Muscidae). Revista Brasileira de Zoologia 6: 325-376.

Carvalho, C.J.B. De. 1989b. Classificação de Muscidae (Diptera): uma proposta através da análise cladística. Revista Brasileira de Zoologia 6: 627-648.

CarvalHo, C.J.B. DE. 2002. Muscidae (Diptera) of the Neotropical Region: taxonomy. Curitiba, Editora Universidade Federal do Paraná, 287p.

Carvalho, C.J.B. De; M.S. Couri; A.C. Pont; D.M. Pamplona \& S. M. LOPES. 2005. A Catalogue of the Muscidae (Diptera) of the Neotropical Region. Zootaxa 860: 1-282.

Costacurta, N. do C.; C.J.B. De Carvalho \& M.S. Couri. 2003a. A new species of Plumispina Albuquerque (Diptera: Muscidae) from Southern Brazil. Proceedings of the Entomological Society of Washington 105: 127-131.

Costacurta, N. C.; R.C. Marinoni \& C.J.B. de Carvalho. 2003b. Fauna de Muscidae (Diptera) em três localidades do Estado de Paraná, capturada com armadilha Malaise. Revista Brasileira de Entomologia 47: 389-397.

Couri, M.S. 2000. A revision of the genus Pilispina Albuquerque (Diptera, Muscidae, Coenosiinae, Coenosiini). Boletim do
Museu Nacional, Nova Série, Zoologia, 437: 1-8.

Couri, M.S. \& D. De O. Albuquerque. 1979. Estudos sobre Neodexiopsis Malloch, 1920 com notas nomenclaturais sobre Coenosiinae (Diptera, Muscidae). Revista Brasileira de Biologia 39: 499-517.

Couri, M.S. \& C.J.B. DE Carvalho. 1993. Parvomusca Medeiros, 1980: redescrição do gênero e descrição de uma espécie nova (Diptera, Muscidae). Revista Brasileira de Entomologia 37: 731-735.

Couri, M.S. \& C.J.B. DE Carvalho. 2002. Part II, Apical Muscidae, p. 133-259. In: C.J.B. DE CARvalho (Ed.). Muscidae (Diptera) of the Neotropical Region: taxonomy. Curitiba, Editora Universidade Federal do Paraná, 287p.

Couri, M.S. \& A.C. Pont. 1999. A key to the world genera of the Coenosiini (Diptera, Muscidae, Coenosiinae). Studia Dipterologica 6: 93-102.

Couri, M.S. \& A.C. Pont. 2000. Cladistic analysis of Coenosiini (Diptera: Muscidae: Coenosiinae). Systematic Entomology 25: 373-392.

HENNIG, W. 1965. Vorarbeiten zu einem phylogenetischen System der Muscidae (Diptera, Cyclorrapha). Stuttgarter Beiträge zur Naturkunde 141: 1-100.

HucketT, H.C. \& J.R. Vockeroth. 1987. Muscidae, p. 115-1131. In: J.F. McAlpine; B.V. Peterson; G.E. Shewell; H.J.Teskey; J.R. Vockeroth \& D.M. Wood (Eds). Manual of Nearctic Diptera. Ottawa, Agriculture Canada, Research Branch, Monograph 28, vol. II, VI+675-1332.

ICZN. 1999. International Code of Zoological Nomenclature. London, The International Trust for Zoological Nomenclature, $4^{\text {th }}$ ed., 306p.

Lopes, S.M.; M.S. Couri; D.M. Pamplona \& C.J.B. de Carvalho. 1997. Notes on the Neotropical types described by Albuquerque. Publicações avulsas do Nacional do Rio de Janeiro 69: 1-33.

McAlpine, J.F. 1981. Morphology and terminology: adults, p. 963. In: J.F. McAlpine; B.V. Peterson; G.E. Shewell; H.J. Teskey; J.R. Vockeroth \& D.M. Wood (Eds). Manual of Nearctic Diptera. Ottawa, Research Branch, Agriculture Canada, Monograph 27, vol. 1, VI+674p.

Rodríguez-Fernández, J.I.; C.J.B. de Carvalho \& M.O. Moura. 2006. Estrutura de assembléias de Muscidae (Diptera) no Paraná: uma análise por modelos nulos. Revista Brasileira de Entomologia 50: 93-100.

Snyder, F.M. 1957. Puerto Rican Neodexiopsis (Diptera: Muscidae: Coenosinae). Journal of Agriculture of the University of Puerto Rico 41: 207-229.

SNyder, F.M. 1958. A review of New World Neodexiopsis (Diptera, Muscidae). The ovata group. American Museum Novitates 1892: 1-27.

Submitted: 28.I.2009; Accepted: 16.I.2010.

Editorial responsibility: Gabriel L.F. Mejdalani

ZOOLOGIA 27 (2): 258-262, April, 2010 